\title{
Subverting Traditional Norms: Against Normalisation in Ama Ata Aidoo's The Dilemma of a Ghost (1965) and Anowa (1970) \\ Abdoulaye Dione
}

Enseignant-Chercheur African and Postcolonial Studies Department of Anglophone Studies Faculty of Arts and Social Sciences Cheikh Anta Diop University, Dakar (Senegal)

DOI: $10.36347 /$ sjahss.2020.v08i01.009

| Received: 05.01.2020 | Accepted: 29.01.2020 | Published: 30.01 .2020

*Corresponding author: Abdoulaye Dione

Abstract

Review Article

The main objective of this article is to demonstrate that in Ama Ata Aidoo's two plays The Dilemma of a Ghost (1965) and Anowa (1970), there are two categories of characters: some who comply with the traditional norms of the Ghanaian society - the conformists - and others who challenge them - the non-conformists. These characters are either displaced or estranged from their own communities or appeared like ghostly figures. Using deconstructionism, the article unearths the conflictual relationships between the traditional and the modern characters born out of the differences in culture and identity. It is also concerned with analyzing how some characters subvert the power and authority of the established system that is torn between tradition and modernity.

Keywords: Ghana, Fanti, (anti-) conformism, tradition, modernity, customs, norms, conflicts, culture, identity, crisis, Africa.

L'objectif principal de cet article est de démontrer que dans les deux pièces d'Ama Ata Aidoo The Dilemma of a Ghost (1965) et Anowa (1970), il existe deux catégories de personnages: certains qui respectent les normes traditionnelles de la société ghanéenne - les conformistes - et d'autres qui les défient- les non-conformistes. Ces personnages sont soit déplacés, soit éloignés de leurs propres communautés, soit ils apparaissent comme des figures fantomatiques. Utilisant le déconstructionnisme, l'article met en évidence les relations conflictuelles entre les personnages traditionnels et modernes nés des différences de culture et d'identité. Il s'agit également d'analyser comment certains personnages subvertissent le pouvoir et l'autorité du système établi, partagé entre tradition et modernité.

Mots clés : Ghana, Fanti, (anti-) conformisme, tradition, modernité, coutumes, normes, conflits, culture, identité, crise, Afrique.

Copyright @ 2020: This is an open-access article distributed under the terms of the Creative Commons Attribution license which permits unrestricted use, distribution, and reproduction in any medium for non-commercial use (NonCommercial, or CC-BY-NC) provided the original author and source are credited.

\section{INTRODUCTION}

Many African women writers are presently expressing ideas about the encounter between Africa and the West, women's status in a male-dominated society and the necessity of social and cultural changes. In other words, African literature has been a protest literature against patriarchy for so long a time because women have always been subjugated and victimized by men. They have been frustrated for not being able to enjoy the same rights dedicated to men. This is witnessed by the beginning of a literature which assesses the true definition of women in a society dominated by patriarchy.

So, a pioneering generation of some prominent female writers has been seeking to revisit, redefine and re-establish an accurate picture of the roles assigned to women through their writings and bring their plight to the attention of their male counterparts. Among them is certainly Ama Ata Aidoo. Claiming that women have been the victims of patriarchy for so long, they are breaking the taboos which subordinate them to men. They are expressing the hidden feelings of the oppressed African women.

However, it would be of paramount importance or even necessary to see how African female writers in general and particularly Ama Ata Aidoo are tackling the issues associated with the women's subjugation. Aidoo is certainly one of the best-known contemporary voices dealing with the encounter between the West and the non-West and the oppression of African women. In other words, she represents the voice of the voiceless. 
Born in 1940, in Abeadzi Kyiakor, in the South of Ghana, Christina Ama Ata Aidoo has grown up in a great Fanti family. From 1961 to 1964 , her father sent her to the Wesley Girls High School which is situated in Cape Coast. In 1964, she went to the University of Ghana, Legon where she got a Bachelor of Arts in English.

As far her career is concerned, Aidoo has served as professor in several universities in Africa and abroad. Being the first woman in charge of the Ministry of Education of Ghana under the regime of Jerry Rawlings, Ama Ata Aidoo is at the same time a writer, a poet, a literary critic, a short-storyteller, etc. As a great literary figure, Aidoo has received many prizes such as the Nelson Mandela Prize for Poetry in 1987 and the Commonwealth Writers Prize for Poetry for Best Book in 1992.

Aidoo's major works include: No Sweetness Here: a Collection of Short-Stories [1], Our Sister Killjoy (or) Reflections from a Black-eyed Squint [2], Someone Talking to Sometime [3], The Eagle and The Chicken and Other Stories [6], Birds and other Poems [4], Changes: A Love Story [5], The Girl who Can and other Stories [7].

Elsewhere, influenced by the events that have shaped the history of her country, particularly the slave trade, colonialism, and neo-colonialism, Aidoo undertakes a wonderful task in her important plays entitled The Dilemma of a Ghost and Anowa.

Ama Ata Aidoo's first play The Dilemma of a Ghost [6] and Anowa [1] are two dilemma tales. The main idea of The Dilemma of a Ghost focuses on a young Ghanaian graduate, Ato Yawson, who goes to the United States in order to study. He comes back with an African-American girl, Eulalie Rush Yawson, his wife. The bone of contention is that Ato's parents do not get on well with the African-American girl and this situation gives birth to a conflictual relationship between the characters of the play. As for the eponymous play Anowa, which is also a dilemma tale, the main idea revolves around a young girl, Anowa, who rebels, defies her parents and espouses a man, Kofi Ako, without her parents' agreement. In both plays, Aidoo raises the issue of women's status in African society.

Aidoo is interested in many themes and issues in both plays. According to Violet Harrington Bryan, "Aidoo explores the themes of self-exile, woman's identity, motherhood, and the African involvement in the slave trade. Aidoo uses the dilemma tale convention in most of her literature to raise issues in which the characters contend" [8]. She writes about the lives of women committed in the quest for self-exploration in Ghana and their wanderings and migrations abroad. Roughly speaking, Aidoo is deeply interested in women's conditions to question their roles in society. She has a realistic description of the Ghanaian society particularly the years following the colonization and she explains the difficulties facing Ghanaians. She denounces patriarchal beliefs and women's oppression because, according to her, women are ostracized and humiliated. She deconstructs the myth according to which men must dominate women. Consequently, she castigates patriarchy that is, the domination of men above women, the consequences of the slave trade, colonialism - British imperialism - in black Africa, and neo-colonialism.

Now what May normalisation suggests in Ama Ata Aidoo's plays, The Dilemma of a Ghost and Anowa? In what way are we using the term normalisation? On which basis may lie the relevance of our topic? From her own experience, Aidoo is conveying a message that concerns all human beings. Thus many people in daily life are abiding by the established norms whereas others are not. So it is of overriding importance to clarify from the beginning what this study will cover and what it will not. We have a strong feeling that human relationships should be based on values and attitudes that govern the society in which they live.

The first part of this article will refer to some characters, in both plays, who are complying with the rules of the traditional Ghanaian society. The last part of this study will attempt to deal with the characters who are not abiding by the rules established.

\section{1-Conformism in the Dilemma of a Ghost and Anowa}

In both plays, some characters are abiding by the rules of the old Ghanaian traditional society. In The Dilemma of a Ghost for instance, Akyere and Mansa, respectively the protagonist's elder and younger aunt, educated in a traditional setting, are conforming to the rules of Ghanaian society. Throughout the play, they are characterized by their conformism. Likewise, this kind of conformism characterizes Petu and Akroma, Ato's elder and younger uncle; they are conforming to the rules of traditional society. Also, Nana, Ato's grandmother, Esi Kom and Monka, respectively Ato's mother and sister, are stuck to traditions. Consequently, they respect the taboos and the superstitions of the society. Their speech expresses their ordinary lives and their daily activities.

It should also be mentioned that in Anowa for example, the same situation happens to characters such as 'The-Mouth-That-Eats-Salt-And-Pepper', symbolized by the old man and the old woman who represent traditional society in the play. In Anowa, the old man and the old woman conform to the norms that their traditional society prescribes. They play completely symbolic roles, introduce and comment on events. The old man points an accusing finger at his 
African compatriots: "It is men who make men mad. Who knows if Anowa would have been a better woman, a better person if we had not been what we are?" [9]. The old woman, on the contrary, represents the voice of emotion and the whole traditional society. She accuses Anowa of having no descendants since in a traditional matrilineal society it is the woman who perpetuates the maternal line. She accuses Anowa and makes her feel guilty.

Seemingly, Osam, Anowa's father who smokes his pipe and Badua, her mother who complains at the beginning and cries at the end, abide by the rules of the traditional society. These characters have a sense of conformism since they respect the norms of traditional society. They are characterized by their Africanity and their rootedness in the traditional values. As the guardians of the old structure, they defend and perpetuate the values of the traditional system set up by their ancestors. All in all, conformists want to perpetuate their community values and traditions. The characters' conformism is determined by their upbringings.

If on the one hand, both plays deal with some particular characters who are copying, imitating, complying with the rules of Ghanaian traditional society in particular - the Ghanaian society is a maledominated society and men are heads of families - and African in general, on the other hand, there are some characters who are not abiding by the rules of this Ghanaian traditional society.

\section{2-Non-conformism or The Bird of the Wayside: Against Normalisation in The Dilemma of a Ghost and Anowa}

In both plays, The Dilemma of a Ghost and Anowa, there are some characters who are not complying with the rules of the old Ghanaian traditional society. The lack of conformism of certain characters creates tensions and conflicts in the two plays.

One of the main characters who challenge and overthrow the traditional norms in The Dilemma of a Ghost is, for instance, Eulalie Rush Yawson, the AfroAmerican graduate and Ato Yawson's wife. The divergences between the couple result in many conflictual situations for various reasons. Indeed, the couple encounters many problems and contradictory situations due to the lack of understanding linked to the generation gap, the power of the traditional beliefs and customs. As a stranger, Eulalie does not know anything about the Odumna clan. This is best exemplified by her behaviour. As she cries out: "I only speak like I was born to speak - like an American!" [6]. In saying so, Eulalie highlights a main difference between African and African-American women. She epitomizes Western education. She is emancipated. Educated in a modern society, she does not abide by the norms of her husband's traditional society. As a matter of fact, the misunderstanding stems from their different educational background. They do not have the same origins, the same values, the same roots, and the same manners. In other words, Ato's relatives and his wife do not have the same culture and identity. Thus, the African traditions are opposed to modern ways from the West. Eulalie's perception of things is different from the way Ato's community understands them. There is a great difference between Eulalie who is an educated woman and Ato's relatives who are mainly illiterate. As such, Eulalie defies the traditional norms and her behaviour is akin to that of the heroine in the eponymous play Anowa. Anowa challenges the traditional standards of her society. Anowa rejects all his suitors and marries Kofi Ako, the man of her own choice. Unfortunately, the husband she chooses is a weak character. Since her parents do not approve of her relationship with Kofi Ako, the latter and Anowa decide to leave Yebi, the family home of the heroine, and escape. Anowa rebels against established standards, challenges parental authority, leaves their supervision and wanders like a ghost. She has left the family home and she has no specific destination, no affiliation or family relationship. Anowa says it clearly: "around I wander like a ghost"[1]. Anowa finds herself in a tragic dilemma since she does not want to conform to the standards that structure traditional society.

Clearly, some characters in both plays, Eulalie and Anowa for instance, challenge the old system and are therefore ostracized or estranged from their native communities.

Moreover, Eulalie - like the trio in Mariama Ba's novel [1] - drinks alcohol and smokes cigarettes, and in African traditional societies, which is a taboo for a woman to indulge in those practices destined to men. He does not want his relatives to see his wife smoking and drinking. A woman who smokes and drinks is not a good wife in African traditional society. Drinking and smoking, for a woman, cannot be associated with wisdom. Referring to Eulalie, Akyere, Ato's elder aunt points out that Eulalie's behaviour is the talk of the town. She exaggerates: "Who does not know that she smokes cigarettes. And who has not heard that she can cut a drink as well as any man" [6]. Imitating her husband's reproaches, Eulalie argues:

Ain't I poorer here as I would ave been in New York City? (...) 'Eulalie, my people say it is not good for a woman to take alcohol. Eulalie, my people say they are not pleased to see you smoke ... Eulalie, my people say... My people... My people...' Damned rotten coward of a Moses (...) I have been drinking in spite of what your people say. (...) Who married me, you or your godamn people? [6]. 
Eulalie defies the Ghanaian traditional society in The Dilemma of a Ghost and subverts the conventions and traditional norms in the sense that she keeps on smoking and drinking in spite of what people say. She argues: "What else would they understand but their own savage customs and standards" [6]. The recurrent clichés, stereotypes, and lexical words used by Eulalie are telling: "Do you compare these bastards, these stupid, narrow-minded savages with us", [6]. She sustains that her parents-in-law have a "prehistoric existence" [6] and are "more savage than dinosaurs", [6]. Meanwhile, Eulalie is in a dilemma because she loves her husband but she hates his relatives. Torn between the undying love she owes her husband and the hatred towards her in-laws, she has her own problems. The relationship that grows between them and its consequences on Ato's and Eulalie's world views are the heart of the play. Eulalie - like Kofi Ako and his inlaws in Anowa - is confronted with the bitter experience of not being accepted by her husband's relatives. The play addresses then the basic predicament of what it is to be rejected and torn between two identities as a human being. Eulalie's fate symbolizes all the African people of the diaspora who have been displaced or deported from Africa to America because of the slave trade. Ato's wife comes from a doubtful background. Considered as a descendant of slaves, Eulalie is like a wayfarer in the eyes of Ato's family because she does not belong, she has no family and no roots. In other words, it is as if she is exiled from her native country and as a matter of fact she keeps on wandering like a ghost or a slave. She is seen like " a black-wife woman / A stranger and a slave " [6]. As such, she is rejected by the family of her in-laws because she does not abide by the social norms of her husband's society. Eulalie's exclusion and rejection by her husband's family is a telling issue in the play. Eulalie is torn between two situations. There is a permanent conflict between Ato Yawson, his relatives and Eulalie in The Dilemma of a Ghost. The issue of identity is a topical issue, paticularly that related to Eulalie. In The Dilemma of a Ghost, the problems stem from Ato who has chosen a wife different from his own people whereas in Anowa the problems originate from Anowa who defies her parents and marries the man she chooses.

Likewise, Anowa challenges also the traditional society by not accepting the choice imposed by her parents and her whole society. She refuses to take root in a wealth based on slavery and rejects the matrilocality which is too conventional for her. Leaving the family in Yebi, her home village, she elopes with her husband and makes up her mind never to return. As such, she defies her parents as she claims: "Mother, I shall walk so well that I will not find my feet back here again', [1].
What needs to be said here is that these two plays stage several characters displaced or estranged from their families or native communities - because they are against the norms - and keep on wandering like ghosts: they are wayfarers. Like Eulalie, Anowa is also a wayfarer. In the action which takes place on the highway, Kofi Ako and Anowa - the couple - leave their homes and are constantly shifting from one place to another. They are deprived of a house, a village, they do not belong. They keep on wandering like ghosts and Anowa does not want to return to Yebi. As she says: "I swore to Mother I was not returning', [1]. As a matter of fact, she is caught on the horns of a dilemma because though she is ill-treated by her husband, she cannot go back home. The unfortunate heroine leaves Yebi and goes from one place to another. It seems as if she is exiled because she does not abide by the social norms. As she cries out: "I am only a wayfarer, with no belongings either here or there'” [1]. Therefore, Aidoo's characters are, in most cases, ostracized. Eulalie and Anowa represent telling figures because of their inbetweeness. These two wayfarers can be seen as "apocalyptic-female figure[s][2] and they are like the bird of the wayside, that is to say, the ghost at Elmina Junction which is split between two positions, or two binary situations. Women like Anowa and Eulalie are oppressed, subjugated and victimized by tradition.

Eulalie and Anowa are not the only characters who are in conflict with the members of the traditional society. Ato Yawson is faced with the same situation, too. Ato is a scholar. He is a "been-to" [3]. Like the bird at the junction which keeps on singing and which does not know if he has to go to Elmina or to Cape Coast, Ato is also confused and he does not know which way to turn. The bird symbolizes Ato's confusion. Ato cannot abide by the rules of his traditional society, nor does he comply fully with the rules of American society. When "The One Scholar" goes abroad and returns to his native country, his relatives come to greet him. They were disappointed because Ato did not even give those seats. As Monka, Ato's sister, points out ironically, alluding to Ato's uprootedness "the way some people become scholars is fearful'" [6]. Ato is uprooted and he is torn, split between two cultures, two identities, and two civilizations; his "double-consciousness"[4] means that he is a man of "two worlds"; therefore, he has obligations towards his family first, he has also obligations towards his wife; so he is divided into two different situations. So far, Esi Kom is still suffering because Ato's situation remains the same though he comes back from the United States. For Esi Kom, Ato's return to his native country would help her get out of her poverty but such is not the case. The whole members of Ato's family sold 'a great part of their land' and gathered huge amounts of money in order to help 
him but they are now disappointed because Ato does not meet their expectations. According to Ato's family, Ato's return from the United States means wealth and prosperity but unfortunately Esi Kom has even debts to pay because of Ato's education and it has been rumoured out that Ato cannot even feed his family: "Esi Kom is not better than she was[6]'".

Another conflict occurs in the plays when the marriage issue is raised. In The Dilemma of a Ghost, for instance, instead of asking Ato news from his journey, his relatives plan to get him married whereas he has already taken a wife without asking them their point of view.

They have already reared a sheep [5] in Ato's name. The bone of contention stems then from the fact that, much to the family's surprise, Ato has already taken a wife and they keep on asking questions particularly associated with the identity of his wife. The following scene tells us much of the reaction of Ato's family:

Ato: [As if just awake from sleep] Ei, Uncle, are you talking of marriage?

Esi: It is nothing. I was only telling your aunt that I have sold your sheep to pay the bride price for you when you make up your mind to marry...

Ato: [Casually] But I am already married, Maami.

ALL: You are married? Married! Married!

Esi: [Overlapping] who is your wife?

Akyere: [Overlapping] when did you marry?

Mansa: Who is your wife?

Monka: [overlapping] what is her name?

Esi: Where does she come from? [6]

A whole confusion is noticed throughout the members of the family who ask Ato important questions associated with identity. Who is your wife? What is her name? When are you married? All these questions are closely linked to identity and it is clear that Ato's Fanti culture is different from Eulalie's African-American culture. The cultural difference shows that some elements can be seen as taboos in the Fanti culture and such may not be the case in Eulalie's culture. The western institution of marriage, which involves sometimes the couple only, is different from the way African people perceive it. Traditional marriage entails the link between the whole members of the family. The African institution of marriage relies heavily on communal life or collective identity whereas the western institution of marriage is based on an individual life or identity whereas. As a case in point, when Ako's elder uncle, Petu, leaves the farm and pays the couple a visit, Eulalie's anxiety is noticeable and she cannot prevent herself from saying: "Oh, this means the whole lot of them will be coming to see us" [6]. And again she addresses Ato in the following terms "Ato, would you care to ask your mother what she wants in our room?''[6]. On top of that, in the scene of the snails, When Ato's mother, Esi Kom, brings food snails and roast - to Eulalie, another problem occurs. Eulalie throws the snails away as she calls them "the horrid creatures" [6]. She refuses to eat them. Her sense of inadaptability is illustrated by her strange behaviour in the eyes of Ato's family. Monka, Ato's sister, informs her mother, letting her know that Eulalie has thrown away the snails Ato's mother has brought to her. Because of the rumours and gossips, Esi Kom falls into disgrace when Eulalie throws the snails away. This makes her unhappy, ashamed and sad because she becomes the laughing-stock of her own society.

Seemingly, the conflictual relationships associated with marriage issues occur, in many instances, in Anowa. Badua, Anowa's mother, says: "any mother would be concerned if her daughter refused to get married six years after her puberty. If I do not worry about this, what shall I worry about' [1]. Badua wants her daughter to get married, but she does not want a man like Kofi Ako. As far as marriage issue is concerned, Kofi Ako and Anowa challenge the traditional norms in this eponymous play since the heroine defies her parents and marries the man she loves against their will. In other words, the parents did not approve of the marriage of their daughter. The conception of the characters as far as marriage is concerned creates divergences in both plays. Ato's relatives look down on Eulalie who is not conforming to the roles assigned to African women. At the same time, Anowa's relatives look down on the lazy Kofi Ako since he is a "good-for-nothing-cassava-man'" [1].

Birth control is also another telling issue in both plays. As for the decision to have children, Eulalie cries out: "Why don't you tell them you promised me we would start having kids when I wanted them' [6]. Eulalie does not have children whereas in traditional societies, children are sources of benediction [10] and prosperity. In African traditional societies, children are sources of benediction; if you have children, you are rich and if you don't have them, you are poor [6]. Childbearing is a fundamental issue in African traditional societies since "a child is more valuable than money" [11]. When the issue of having children is raised, there is a serious problem, Petu; Ato's elder uncle cannot help from saying to Ato that "when two people marry, everyone expects them to have children. For men and women marry because they want children" [12]. Ato's relatives think that Eulalie has a disease that prevents her from having a child. The same thing happens to Anowa who has no descendants and we know that being from a matrilineal society where women are the quintessence of life because they ensure 
the continuity of the maternal line, she can in no way claim to have any happiness. In African traditional societies, if a married woman is barren, people often say that this marriage is not fruitful. A married woman needs off-springs and this highlights the importance of children in any couple. Lacking a child, for the couple, can be seen as a kind of failure or a curse.

Overall, the conflictual relationships between the characters can be associated with the opposition between tradition and modernity and African values against American ways of life. Eulalie epitomizing American society whereas Ato represents Africa.

\section{CONCLUSION}

At the end of our analysis, it is of pivotal interest to highlight the theme of our research. It is about the subversion of the traditional norms: against normalisation in Ama Ata Aidoo plays, The Dilemma of $a$ Ghost and Anowa.

It has been shown, on the one hand, that many characters in both plays respect the traditional norms of the Ghanaian traditional society. On the other hand, some of them challenge these norms and are against the established rules.

If Anowa epitomizes the conflict between tradition and modernism, the rebellion against parental authority and the subversion of power, the Dilemma of $a$ Ghost symbolizes the clash between Africa and America, the encounter between the West and the nonWest. To cut a long story short, in her play Aidoo tries to hint at, allude to the generation gap embodied by Eulalie, her husband and her parents-in-laws. Being educated according to the western way, she cannot fully accept the rules imposed by the traditional African society. That situation gives birth to conflictual relationships between the characters. There is a permanent conflict between two cultures, two identities and two civilizations. It is also a conflict between the individual and his community, between tradition and modernity. Ato is torn between these conflictual situations. The diversities between the two cultures African and african-american - create tensions in the play. These tensions affect many sectors of the society such as love, marriage issues, barrenness and childbearing.

Anowa and The Dilemma of a Ghost deal with a patriarchy-dominated society. The heroines of both plays epitomize the conflict between tradition and modernism, between Africa and her diaspora. They embody a perpetual rebellion against the established norms, a rebellion against power and parental authority. As such, they challenge patriarchy and authority, and transgress the social standards. Both plays encapsulate the psychological dimension of the characters and their sufferings, the permanent conflict of culture as it is illustrated the African culture is embodied by Ato's family and the American culture which is epitomized by Eulalie. Is it possible to reconcile these two cultures? The Dilemma of a Ghost and Anowa are both dilemma tales. In Anowa, there is no solution to solve the dilemma and the bad ending of the play epitomized by the deaths of the couple is a perfect iluustration of their tragedy whereas in The Dilemma of a Ghost, Esi Kom, the protagonist's mother, succeeds in solving the dilemma. She plays this role because she accepts Eulalie at the very end of the play; this illustrates the writer's panafricanist agenda, that is, her goal to bridge the gap between these two cultures. The roles ascribed to women is very important.

In both plays, Aidoo uses a simple style in order to be closer to her audience. The use of proverbs is also another main component of orature. Therefore, Aidoo's art lies in her ability to rely on oral tradition exemplified in her use of the dilemma tale. There is a play within the play illustrated by the presence of the two children. Aidoo is committed to denouncing the bad treatment of women. She is the spokerperson and the voice of the voiceless; she has a realistic social vision that consists in delivering a message. The cornestone of her writing is the relationships between African-Americans and Africans, a recurrent theme in Ama Ata Aidoo's works particularly in The Dilemma of the Ghost and Anowa.

\section{NOTES}

${ }^{1}$ In Mariama Ba's novel, Yacine, Arame, and Dieynaba indulge in those practices.

2 Dione asserts that if the mythical female figure embraces conventions, the apocalyptic-figure subverts them. ${ }^{1}$

3 The term" "been-to" in African literature is a pejorative term referring to a person who leaves his country and stays abroad for many years. The figure of the 'been-to' is a recurrent theme describing then someone who receives an American or a European education so much so that he becomes enamoured of the West and forgets, underestimates or denigrates his own African values. Lakunle in Wole Soyinka' The Lion and The Jewel, Obi, the protagonist, in Chinua Achebe's No Longer at Ease, Samba Diallo in Ambiguous Adventure are examples of 'ben-tos'. The term is also exemplified in Fatou Diome's The Belly of the Atlantic. The "been-to" figure is torn between two identities, two cultures and two civilisations. He is first and foremost an alienated African and on top that he has received a westernized education he does not fully assimilate, in this sense, he is a kind of a dilemma because he is no longer a genuine African because he does not know which way to turn. He is hybrid

${ }^{4}$ We borrow the expression from William Edward Burghardt Dubois. In the terms of Dubois, the term means divided self, twoness, duality, ambivalence or hybridity. 
${ }^{5}$ Esi Kom, Ato's mother, during a good market day, sells the sheep in order to find more money and makes her mind to give it to Ato's father to pay for the bride price for its owner.

${ }^{6}$ Cf Flora Nwapa, Idu, London, and Ibadan: Heinemann Educational Books, 1970 and Efuru, London; Ibadan; Nairobi: Heinemann Educational Books, 1973. Like Emecheta, Nwapa highlights the importance of children in traditional societies.

\section{REFERENCES}

1. Aidoo, Christina Ama Ata, Anowa, Hong Kong : Longman; 1970.

2. Aidoo, Christina Ama Ata, Our Sister Killjoy (or) Reflections from a Black-eyed Squint, London: Longman; 1977.

3. Aidoo, Christina Ama Ata, Someone Talking to Sometime, Harare: College Press; 1985.

4. Aidoo, Christina Ama Ata, Birds and other Poems, Harare: College Press; 1987.

5. Aidoo, Christina Ama Ata, Changes: A Love Story, London: The Women's Press; 1991.
6. Aidoo, Christina Ama Ata, The Dilemma of a Ghost, Longman Group Limited; 1965.

7. Aidoo, Christina Ama Ata, The Girl who can and other Stories, Accra: Sub-Saharan Publishers; 1997.

8. Bryan, Violet Harrington, "Conflicting Identities in the Women of Ama Ata Aidoo's Drama and Fiction", in: Elisabeth Brown-Guillory (ed.), Middles Passages and the Healing Place of History: Migration and Identity in Black Women's Literature, Columbus: The Ohio State University Press. 2006: 15-31.

9. Aidoo, Christina Ama Ata, No Sweetness Here: a Collection of Short-Stories, London: Heinemann; 1972.

10. Emecheta, Buchi, the Joys of Motherhood, London, Ibadan, Nairobi: Heinemann; 1982.

11. Nwapa, Flora, Idu, London; Ibadan: Heinemann Educational Books; 1970.

12. Aidoo, Christina Ama Ata, the Eagle and the Chicken and other Stories, Tana Press, Enugu; 1986. 